\title{
Phenotypic correlations among meat quality traits in broilers
}

\author{
Correlações fenotípicas entre características de qualidade de carne em frangos
}

\section{Luana Bertollini de Jesus Silva'* Leila de Genova Gaya ${ }^{\text {II }}$ Ana Paula Madureira' ${ }^{I I}$ Graziela Tarôco ${ }^{\mathrm{I}}$ José Bento Sterman Ferraz ${ }^{\mathrm{III}}$ Gerson Barreto Mourão ${ }^{\mathrm{IV}}$ Elisângela Chicaroni de Mattos ${ }^{\mathrm{II}}$ Tércio Michelan Filhov}

\begin{abstract}
The goals of this research were to estimate the phenotypic correlations among various meat quality traits from a male broiler line and to describe the relation among these variables. Phenotypical correlations were determined among quality traits, isolating the effects of slaughter date, the age of the mother and sex. The evaluated traits were $\mathrm{pH}$ measurements taken at time 0 and at 6 and 24 hours after slaughtering, color parameters, water loss due to exudation, thawing and cooking of the meat, and shear force. Important associations $(P<0.01)$ were found to be significant and, in most cases, weak or moderate, varying from -0.35 to 0.28 . The initial $\mathrm{pH}$ of the meat was not associated $(P>0.05)$ to the other traits of the meat, whereas the $\mathrm{pH}$ at 24 hours after slaughter was able of directly interfering with the attributes of the meat, since this trait was inversely related with lightness and water losses, which indicates an effect of $\mathrm{pH}$ fall along $24 \mathrm{~h}$ after slaughtering on protein denaturation. This study demonstrates that the variables of poultry meat quality are related and that there is a phenotypical association between lightness and cooking losses and the other attributes of the meat. The pH at 24 hours after slaughtering, lightness and cooking losses could be efficient meat quality indicators in this broiler line.
\end{abstract}

Key words: correlation, Pectoralis major, $p H$, poultry.

RESUMO

O objetivo desta pesquisa foi estimar as correlações fenotípicas entre as características de qualidade de carne de uma linhagem macho de frangos de corte. Para tanto, foram determinadas as correlações fenotípicas entre essas características, isolando-se os efeitos de data de abate, idade da mãe e sexo. As características avaliadas foram: medidas de pH inicial, em 6 e em 24 horas após o abate, parâmetros de cor, perdas por exsudação, descongelamento e cozimento da carne e força de cisalhamento. A maioria das associações obtidas foi de intensidade fraca a moderada, porém significativa, com magnitude variando entre $-0,35$ e 0,28. $O$ pH inicial da carne não esteve associado de modo importante com as outras características de qualidade de carne (P>0,05), enquanto o pH em 24 horas após o abate interferiu diretamente nos atributos da carne $(P<0,01)$, estando inversamente relacionado com o teor de luminosidade e as perdas de água da carne, indicando um efeito da queda do pH ao longo das 24 horas após o abate na desnaturação protéica. Comprovouse a existência da relação entre as variáveis de qualidade de carne em aves, havendo associação fenotípica entre o teor de luminosidade $e$ as perdas por cozimento $e$ as demais características avaliadas. Dessa forma, o pH em 24 horas após o abate, o teor de luminosidade e as perdas por cozimento da carne podem ser indicadores eficientes da qualidade da carne na linhagem estudada.

Palavras-chave: aves, correlação, Pectoralis major, $p H$.

\section{INTRODUCTION}

In recent years, the Brazilian chicken agribusiness has been showing a great increase in its

\footnotetext{
${ }^{I^{*} C u r s o ~ d e ~ Z o o t e c n i a, ~ U n i v e r s i d a d e ~ F e d e r a l ~ d e ~ S a ̃ o ~ J o a ̃ o ~ d e l-R e i ~(U F S J), ~ 36301-160, ~ S a ̃ o ~ J o a ̃ o ~ d e l-R e i, ~ M G, ~ B r a s i l . ~ E-m a i l: ~}$ luanabertollini@ hotmail.com. *Autor para correspondência.

"Departamento de Engenharia de Biossistemas, UFSJ, São João del-Rei, MG, Brasil.

"IIFaculdade de Zootecnia e Engenharia de Alimentos, Universidade de São Paulo (USP), Pirassununga, SP, Brasil.

${ }^{\mathrm{IV}}$ Escola Superior de Agricultura Luiz de Queiroz (ESALQ), Universidade de São Paulo (USP), Piracicaba, SP, Brasil.

${ }^{v}$ Aviagen do Brasil Ltda., Rio Claro, SP, Brasil.
} 
production volume, and chicken is becoming a major item on the national exports. To reach this stage, improvements in handling practices and feeding, as well as changes in the strategies of breeding programs to meet the demands of production markets, industry and costumers are fundamental. However, according to ANTHONY (1998), genetic progress that has increased the size of the poultry has also decreased meat quality, and, according to SAMS (1999), it does not help to increase muscle deposition of the birds when the meat is of low quality because the sensory properties of meat have important influences on the purchasing decisions and product acceptance by consumers.

According to DIRINCK et al. (1996), one of the greatest challenges for the meat industry is to offer products that are tender, juicy and have good color and flavor. For FERNANDEZ et al. (2002), the return after meat processing is highly related to decreases in $\mathrm{pH}$ post mortem. Therefore, the difference of one less unit in measured $\mathrm{pH}$ at 20 minutes post mortem corresponds to around $2 \%$ less return after meat processing. According to MOLETTE et al. (2003), a decrease in muscle $\mathrm{pH}$ while the temperature of the carcass is still high could lead to denaturation of muscle protein, which changes meat properties.

OLIVO et al. (2001) reported that the scattering of light from a muscle surface is directly proportional to its amount of protein denaturation, which prejudices the physical appearance of meat, thus influencing the quality of light that is reflected. The greater the degree of protein denaturation, the less light is transmitted through the fibers and the more light ends up being dispersed, which leads to a pale meat color. According to OFFER \& KNIGHT (1988), $\mathrm{pH}$ and temperature could also to influence the capability of water retention in meat and the decline in extracellular $\mathrm{pH}$ changes and in the cellular composition of muscle fibers, resulting in a reduction in the number of reactive groups that are available to keep water in muscle protein. Therefore, it is understood that $\mathrm{pH}$ can have a great influence on water loss during exudation, thawing and cooking of the meat. In addition, according to ANADÓN (2002), the water retention capacity influences meat tenderness, so that the lower the water contents of muscle, the lower its meat tenderness.

In this context, the study of the relationships among meat quality variables could contribute to identifying the degree of association among them, which could be identified by the calculation of correlations. Phenotypic correlations measure the relation between two variables and their degree of association, involving both genetic and environmental factors.
Therefore, the goal of this study was to estimate the phenotypic correlations among quality traits of broiler meat to characterize the relations among meat quality variables.

\section{MATERIAL AND METHODS}

The utilized database was composed of information about the meat quality of broilers and its possible sources of variation, made available by the group of Animal Breeding and Biotechnology, College of Animal Science and Food Engineering of the University of São Paulo. Sibs from an elite flock that had undergone selection for development of a male line were used. Pedigree chicks were wing banded at hatching and housed and raised as recommended by the company guidelines for nutritional planning, management conditions and vaccination on a breeder unit.

From May 2005 to March 2006, each flock of approximately 200 broilers at $44 \mathrm{~d}$ of age was transported to the Experimental Processing Plant (Pirassununga, São Paulo, Brazil), to measure the meat quality and carcass for a total of 13 dates of slaughter. The birds were submitted to a minimum of $10 \mathrm{~h}$ of feed withdrawal prior to slaughter and were held in transportation crates. The transportation of the broilers to the processing plant occurred during the night and lasted about $6 \mathrm{~h}$ and they were allowed to rest about $2 \mathrm{~h}$ before slaughtering. The processing plant was semiindustrial. The voltage used for electric shock in the stunning of the birds was $40 \mathrm{~V}$, at $60 \mathrm{~Hz}$ and an average of $45 \mathrm{~mA}$ per bird, for 9 seconds. Processing speed was carried out to allow adequate time to perform all measurements. The bleeding of the birds lasted 3 minutes. Prior to feather removal, the birds were immersed in water at $57^{\circ} \mathrm{C}$ for 2 minutes. After evisceration, the carcasses were chilled at $0-4^{\circ} \mathrm{C}$ within water and ice before stored at $0-2^{\circ} \mathrm{C}$ for $24 \mathrm{~h}$ and then deboned. Meat quality data from the sib test flock were all measured in the Pectoralis major muscle and collected as follows:

$\mathrm{pH}$ measurements: The $\mathrm{pH}$ of the meat was measured three times: initial $\mathrm{pH}$, measured 15 minutes after slaughter ( $\mathrm{pH} 0), \mathrm{pH}$ measured 6 hours after slaughter (pH6), and $\mathrm{pH}$ measured 24 hours after slaughter ( $\mathrm{pH} 24)$. The $\mathrm{pH}$ measurements were taken using a digital $\mathrm{pH}$ meter in the cranioventral side at the proximal half of the Pectoralis major muscle. Parameters of color: Amount of lightness $\left(\mathrm{L}^{*}\right)$, redness $\left(\mathrm{a}^{*}\right)$, and yellowness of the meat $\left(b^{*}\right)$ were determined. These color parameters were evaluated by the CIELab System, with the help of a portable colorimeter. These measurements 
were performed in the Pectoralis major muscle on its ventral side 24 hours after slaughter at three different places in the muscle and the average of these measurements was used. Water loss and meat tenderness: To determine water loss of meat per exudation (EXSU), 24 hours after slaughter, a sample of the Pectoralis major muscle was weighed, wrapped in a mesh and suspended in a plastic bag filled with air. The samples were refrigerated $\left(0^{\circ} \mathrm{C}\right)$, and after 24 hours were weighed again. The difference in percentage between the initial and final weight corresponded to the water loss by exudation. To determine the water loss of the meat due to thawing (THAW), 24 hours after slaughter, samples of the Pectoralis major muscle were placed in plastic bags and kept in the freezer at $18^{\circ} \mathrm{C}$. The samples were thawed in a refrigerator at $4^{\circ} \mathrm{C}$ and then weighed. The difference in percentage between the initial and final weight corresponded to the loss of water by thawing. The water loss of the meat during cooking $(\mathrm{COK})$ was calculated using the samples that were used to find the losses due to thawing. The samples, after having been thawed and weighed, were roasted in an electric oven until they reached an internal temperature of about $72^{\circ} \mathrm{C}$. The samples were then cooled at room temperature and weighed again. The difference in percentage between the initial and final weight corresponded to the loss of water after cooking. After having been roasted and cooled at room temperature, the sample that was used to determine water loss after cooking was used to analyze the shear force. From these samples, four blocks of $2 \times 2 \times 1 \mathrm{~cm}$ were sheared off with a blade of a Warner Bratzler device. The average force obtained from the four blocks was taken as the value of shear force of the sample and was expressed in $\mathrm{kg}$. The samples were placed with the fibers oriented in the perpendicular direction in relation to the blade.

The possible co-variables for the meat quality variables identified in the database were initial temperature of the meat (measured right after slaughter), temperature of the meat 6 hours after slaughter, temperature of the meat 24 hours after slaughter, initial size of sample for exudation loss measurements, initial size of sample for thawing loss measurements and initial size of sample for cooking loss measurements. The database was organized by the software Visual Fox $\mathrm{Pro}^{\circledast}$ (VIDAL, 1994), and the extreme values, outliers, were identified using the box-plot procedure and removed from the data set.

Subsequently, descriptive statistics of the meat quality traits and their possible co-variables previously described were studied by the PROC MEANS command of the SAS ${ }^{\circledR}$ software (1999). The generalized linear model method was performed by PROC GLM of the SAS software. In this model, the meat quality traits were considered as the dependent variables, on which the possible effects of co-variables and sources of variation were tested. These sources of variation were: the type of diet (level 1 for pelletted feed and level 2 for crumbled feed); sex (level 1 for males and level 2 for females); age of the mother (5 different levels: $35,39,43,52$ and 56 weeks); and date of slaughter ( 9 different levels, from 06/03/2004 to 09/ 19/2005). A p-value less than 0.05 was considered statistically significant.

Based on the obtained models, the phenotypic correlations were estimated using the PROC CORR procedure of the SAS software. The programming function PARTIAL was used within this procedure in order to control the sources of variations which found to be significant in the previous general linear models analysis. The partial correlation establishes the degree of association between two variables after the influence of a third factor was controlled (HENRIQUES et al., 2004).

\section{RESULTS AND DISCUSSION}

Table 1 shows descriptive statistics of the quality variables of meat and their possible co-variables. The low magnitude for skewness obtained for all the variables could not bring an expressive attenuation to the correlations estimates. Different combinations of sources of variation and co-variables for the determination of the models for the variables of chicken meat quality were used. The models used in the analyses of meat quality are shown in table 2 .

Based on the obtained models, it was observed that the date of slaughter had a great influence on the studied variables, a result that could possibly be associated with the set of environmental conditions in which the birds were placed on the days of slaughter. These conditions may influence the chicken meat quality, as suggested by BROSSI et al. (2008). These authors reports that the conditions to which animals are submitted on the day of slaughter can affect the parameters of meat quality because stress can trigger a rapid drop in $\mathrm{pH}$. Sex affected the majority of the meat quality variables studied $(\mathrm{P}<0.01)$, a finding that is in contrast to that of MOREIRA et al. (2004), who state that the sex of the chicken does not affect meat quality. The physical type of feed in the models had no effect on the evaluated traits $(\mathrm{P}>0.05)$.

The sources of variation identified as being significant for each trait were used to determine the correlations presented in table 3 , in which can be found 
Table 1 - Number of observations (N), mean (M), standard deviation (SD), skewness (SKW) and kurtosis (KUR) of the meat quality traits analyzed and their possible co-variables.

\begin{tabular}{|c|c|c|c|c|c|}
\hline Variables & $\mathrm{N}$ & M & SD & SKW & KUR \\
\hline pH0 & 942 & 6.12 & 0.18 & 0,10 & -0.38 \\
\hline pH6 & 933 & 5.96 & 0.17 & 0.20 & -0.35 \\
\hline $\mathrm{pH} 24$ & 2,125 & 5.80 & 0.13 & 0.42 & -0.07 \\
\hline $\mathrm{L}^{*}$ & 2,134 & 56.06 & 2.99 & -0.16 & -0.29 \\
\hline$a^{*}$ & 1,659 & 5.81 & 0.91 & 0.10 & -0.10 \\
\hline$b^{*}$ & 1,733 & 14.30 & 1.53 & -0.34 & -0.21 \\
\hline EXSU (\%) & 2,119 & 2.19 & 1.12 & 0.36 & 0.05 \\
\hline THAW (\%) & 2,131 & 6.46 & 3.23 & 0.71 & 0.26 \\
\hline $\operatorname{COK}(\%)$ & 2,125 & 21.24 & 4.19 & -0.13 & -0.15 \\
\hline \multirow[t]{2}{*}{$\mathrm{SF}(\mathrm{kg})$} & 2,119 & 1.21 & 0.41 & 0.75 & 0.27 \\
\hline & & Co-varial & es-----. & - & ---- \\
\hline Temp0 $\left({ }^{\circ} \mathrm{C}\right)$ & 942 & 31.53 & 1.95 & -0.01 & -0.50 \\
\hline Temp6 $\left({ }^{\circ} \mathrm{C}\right)$ & 942 & 14.26 & 1.74 & -0.23 & -0.33 \\
\hline Temp24 $\left({ }^{\circ} \mathrm{C}\right)$ & 2,143 & 13.25 & 2.09 & 0.15 & -1.01 \\
\hline EXSUI (g) & 170 & 55.65 & 9.10 & -0.18 & 1.18 \\
\hline CONGI (g) & 2,136 & 169.55 & 27.92 & 0.06 & 0.11 \\
\hline CONGF (g) & 2,133 & 158.84 & 27.97 & 0.05 & -0.05 \\
\hline
\end{tabular}

$\mathrm{pH} 0=\mathrm{pH}$ of the meat 15 minutes after slaughter; $\mathrm{pH} 6=\mathrm{pH}$ of the meat 6 hours after slaughter; $\mathrm{pH} 24=\mathrm{pH}$ of the meat 24 hours after slaughter; $\mathrm{L}^{*}=$ lightness of the meat; $\mathrm{a}^{*}=$ redness in the meat; $b^{*}=$ yellowness of the meat; EXSU $=$ loss of water from meat by exudation; THAW $=$ loss of water from meat by thawing; $\mathrm{COK}=$ loss of water from meat by cooking; $\mathrm{SF}=$ shear force of the meat; temp $0=$ temperature of the meat 15 minutes after slaughter; temp6 = temperature of the meat 6 hours after slaughter; temp $24=$ temperature of the meat 24 hours after slaughter; EXSUI = initial weight of the sample before exudation; CONGI = initial weight of the sample before thawing; CONGF = initial weight of the sample before cooking.

that the associations found between the $\mathrm{pH} 0$ and the variables $\mathrm{pH} 6, \mathrm{pH} 24, \mathrm{~L}^{*}, \mathrm{~b}^{*}, \mathrm{COK}$ and $\mathrm{SF}$ were not significant. However, the variables $\mathrm{a}^{*}$, EXSU and THAW presented positive and significant correlations, although they were weak.

Therefore, in this study, pH0 had not influence upon the studied variables. The initial $\mathrm{pH}$ had no significant influence on the ability to retain water in the analyzed lineage, a result that differs from the one reported by LE BIHAN-DUVAL (2004), who observed a moderate correlation between the initial $\mathrm{pH}$ of the meat and its moisture losses, indicating that the decline in $\mathrm{pH}$ post mortem would change the cellular and extracellular compositions of muscle fibers, resulting in reduction of reactive groups available on protein to retain water. Additionally, an increase in the shear force of the meat was not observed in the present study. Likewise, a decrease in the initial $\mathrm{pH}$ of meat did not affect the meat color, a result that differed from the one reported by OLIVO et al. (2001).
The variable pH6 showed positive and significant correlations with $\mathrm{a}^{*}$ and EXSU, and significant and negative associations with $\mathrm{pH} 24$; all of these associations were of low magnitude, with values ranging from 0.14 to -0.10 . This inverse correlation between $\mathrm{pH} 6$ and $\mathrm{pH} 24$ could be due to the speed of the $\mathrm{pH}$ falling along the 24 hours after slaughtering, since the protein denaturation could remain after 6 hours after slaughtering. Therefore, the higher the $\mathrm{pH}$ at 6 hours, the higher its falling until 24 hours. No significant correlation was found between $\mathrm{pH} 6$ and other variables.

There were significant inverse correlations between $\mathrm{pH} 24$ and all studied variables, except for those with $\mathrm{pH} 0$ and $\mathrm{a}^{*}$, for which the correlations were not significant. An inverse and moderate correlation of 0.30 found between $\mathrm{pH} 24$ and $\mathrm{L}^{*}$ suggests that the meat of the studied strain tends to present greater lightness when the $\mathrm{pH} 24$ is smaller, indicating the occurrence of protein denaturation 24 hours after slaughter. This is in agreement with the results of LE BIHAN-DUVAL et al. (2003), who reported that the greater the degree of protein denaturation, the less the amount of light transmitted through the fibers and the more light that is dispersed, which makes the meat pale. DEBUT et al. (2003) also found negative and moderated correlations between the lightness of the meat and the $\mathrm{pH} 24$ hours after slaughter.

The correlations between the values of $\mathrm{pH} 24$ and the variables $\mathrm{b}^{*}$, EXSU and COK were of low magnitude, with values ranging from -0.13 to -0.14 . The association between $\mathrm{pH} 24$ and THAW was inverse and moderate, suggesting that the magnitude of $\mathrm{pH} 24$ can also influence in the water losses during meat thawing. The variables $\mathrm{pH} 24$ and SF presented an inverse and moderate association, suggesting that lower $\mathrm{pHs}$ of meat 24 hours after slaughter can also lead to increased shear force, which could be determined, indirectly, by the association found between $\mathrm{pH} 24$ and THAW, because, according to ANADÓN (2002), the lower the water retention capacity of meat, the less tender it tends to be.

Therefore, among the pH6 and $\mathrm{pH} 24$ measurements, more favorable associations with attributes of meat quality were observed, whereas the initial measurements of $\mathrm{pH}$ showed no significant associations with these attributes in the strain studied.

L* demonstrated significant correlations with all variables, except $\mathrm{pH} 0$ and $\mathrm{pH} 6$. Its inverse correlation was moderated only with $\mathrm{a}^{*}(-0.35)$, suggesting that the higher the level of lightness, the lower the redness of the chicken meat. The correlations between the variables $\mathrm{L}^{*}$ and THAW (0.23) and between 
Table 2 - Variation sources and significant co-variables $(\mathrm{P}<0.05)$ for the studied meat quality traits.

\begin{tabular}{llc}
\hline Variables & \multicolumn{1}{c}{ Variation sources and significant co-variables } & $\mathrm{R}^{2}$ \\
\hline $\mathrm{pH} 0$ & Date of slaughter, age of the mother, temp0 & 0.99 \\
$\mathrm{pH} 6$ & Date of slaughter, age of the mother, sex, temp6 & 0.98 \\
$\mathrm{pH} 24$ & Date of slaughter, age of the mother, sex, temp24 & 0.99 \\
$\mathrm{~L}^{*}$ & Date of slaughter, age of the mother, sex, temp0, pH0 & 0.99 \\
$\mathrm{a}^{*}$ & Date of slaughter, sex, pH0 & 0.95 \\
$\mathrm{~b}^{*}$ & Date of slaughter, age of the mother, sex & 0.96 \\
EXSU $(\%)$ & Date of slaughter, sex, EXSUI, pH0, temp0 & 0.31 \\
THAW $(\%)$ & Date of slaughter, CONGI & 0.25 \\
COK $(\%)$ & Date of slaughter, sex, CONGF, pH0, temp0 & 0.94 \\
SF $(\mathrm{kg})$ & Date of slaughter, age of the mother, sex, pH0, temp0 & 0.92 \\
\hline
\end{tabular}

$\mathrm{pH} 0=\mathrm{pH}$ of the meat 15 minutes after slaughter; $\mathrm{pH} 6=\mathrm{pH}$ of the meat 6 hours after slaughter; $\mathrm{pH} 24=\mathrm{pH}$ of the meat 24 hours after slaughter; $\mathrm{L}^{*}=$ lightness of the meat; $\mathrm{a}^{*}=$ redness in the meat; $\mathrm{b}^{*}=$ yellowness of the meat; EXSU $=$ loss of water from meat by exudation; THAW = loss of water from meat by thawing; $\mathrm{COK}=$ loss of water from meat by cooking; $\mathrm{SF}=$ shear force of the meat; temp0 = temperature of the meat 15 minutes after slaughter; temp $6=$ temperature of the meat 6 hours after slaughter; temp $24=$ temperature of the meat 24 hours after slaughter; EXSUI = initial weight of the sample before exudation; CONGI = initial weight of the sample before thawing; CONGF $=$ initial weight of the sample before cooking.

$\mathrm{R}^{2}=$ coefficient of determination of model.

$\mathrm{L}^{*}$ and $\mathrm{COK}(0.24)$ suggest that the higher the lightness, the greater the loss of water due to thawing and cooking of meat. This water loss may be due to the mechanism of protein denaturation, which can lead to meat being pale and to a lower capacity of water retention. So, this meat could lose more water during the cooking and freezing processes, proving the existence of important relationships among these traits.

The estimates of correlations found among $\mathrm{L}^{*}$ and the variables $\mathrm{b}^{*}$, EXSU and SF were of low magnitude, with values ranging from 0.10 to 0.13 . The variable $\mathrm{a}^{*}$ showed a weak positive and significant correlation with the variables THAW and SF (0.09 and 0.18 , respectively). The correlation between $\mathrm{a}^{*}$ and $\mathrm{b}^{*}$ was positive and of moderated intensity (0.33). According to LE BIHAN-DUVAL et al. (1999; 2001), the redness and yellowness of chicken are linked, such that meat with higher redness tends to present higher levels of yellowness, similar to the association found in this study. The variable $\mathrm{a}^{*}$ had no significant associations with EXSU and COK.

The variable $b^{*}$ had a moderate and significant correlation with the variable $\mathrm{SF}(0.22)$ and a weak correlation with THAW (0.11) but did not have significant correlations with the variables EXSU and COK. EXSU had a significant but weak positive correlation with the variable THAW (0.12), and it did not have significant associations with COK or FC.

Table 3 - Estimates of partial phenotypical correlations among analyzed meat quality traits.

\begin{tabular}{|c|c|c|c|c|c|c|c|c|c|}
\hline & $\mathrm{pHO}$ & pH6 & $\mathrm{pH} 24$ & $\mathrm{~L}^{*}$ & $a^{*}$ & $b^{*}$ & EXSU & THAW & $\mathrm{COK}$ \\
\hline pH6 & $-0.02^{\mathrm{NS}}$ & - & - & - & - & - & - & - & - \\
\hline pH24 & $-0.04^{\mathrm{NS}}$ & $-0.10^{*}$ & - & - & - & - & - & - & - \\
\hline $\mathrm{L}^{*}$ & $-0.01^{\mathrm{NS}}$ & $0.03^{\mathrm{NS}}$ & $-0.30^{*}$ & - & - & - & - & - & - \\
\hline$a^{*}$ & $0.13^{*}$ & $0.12^{*}$ & $-0.07^{\mathrm{NS}}$ & $-0.35^{*}$ & - & - & - & - & - \\
\hline$b^{*}$ & $0.03^{\mathrm{NS}}$ & $0.02^{\mathrm{NS}}$ & $-0.13^{*}$ & $0.13^{*}$ & $0.33^{*}$ & - & - & - & - \\
\hline EXSU & $0.12^{*}$ & $0.14^{*}$ & $-0.14^{*}$ & $0.11^{*}$ & $0.07^{\mathrm{NS}}$ & $0.03^{\mathrm{NS}}$ & - & - & - \\
\hline THAW & $0.11^{*}$ & $0.05^{\mathrm{NS}}$ & $-0.25^{*}$ & $0.23^{*}$ & $0.09^{*}$ & $0.11^{*}$ & $0.12^{*}$ & - & - \\
\hline $\mathrm{COK}$ & $-0.01^{\mathrm{NS}}$ & $-0.01^{\mathrm{NS}}$ & $-0.14^{*}$ & $0.24^{*}$ & $-0.05^{\mathrm{NS}}$ & $0.04^{\mathrm{NS}}$ & $0.05^{\mathrm{NS}}$ & $0.41 *$ & - \\
\hline SF & $0.01^{\mathrm{NS}}$ & $0.00^{\mathrm{NS}}$ & $-0.30^{*}$ & $0.10^{*}$ & $0.18^{*}$ & $0.22^{*}$ & $0.05^{\mathrm{NS}}$ & $0.09 *$ & $0.28 *$ \\
\hline
\end{tabular}

$\mathrm{pH} 0=\mathrm{pH}$ of the meat 15 minutes after slaughter; $\mathrm{pH} 6=\mathrm{pH}$ of the meat 6 hours after slaughter; $\mathrm{pH} 24=\mathrm{pH}$ of the meat 24 hours after slaughter; $\mathrm{L}^{*}=$ lightness of the meat; $\mathrm{a}^{*}=$ redness in the meat; $\mathrm{b}^{*}=$ yellowness of the meat; EXSU $=$ loss of water from meat by exudation; THAW = loss of water from meat by thawing; $\mathrm{COK}=$ loss of water from meat by cooking; $\mathrm{SF}=$ shear force of meat; NS = non significant. $*=(\mathrm{P}<0.05)$

Ciência Rural, v.41, n.8, ago, 2011. 
The variable THAW had significant and positive correlations with the variables $\mathrm{COK}$ and FC. The association found between THAW and COK was of moderate intensity (0.41), suggesting that the higher the water loss when thawing the meat, the greater its water loss was during cooking as well. The correlation between THAW and SF was weak (0.09).

COK had a significant and positive correlation with SF (0.28). According to ANADÓN (2002), the texture of the meat is closely related to the amount of intramuscular water and, thus, to the water retention capacity of the meat. Therefore, the higher the water content fixed in the muscle, the greater the tenderness of the meat. This property was demonstrated in this study only for the relation between COK and $\mathrm{SF}$. Therefore, the existence of associations among COK and the other attributes of meat quality were observed, proving the interrelations among these variables, in accordance with results described by LE BIHANDUVALet al. (2001).

\section{CONCLUSION}

The $\mathrm{pH}$ at 24 hours after slaughtering is an efficient meat quality indicator, an effect that is not observed for the initial $\mathrm{pH}$ of the meat.

There are phenotypic associations between the lightness and cooking losses of meat and other meat quality attributes, suggesting that there are relationships among the variables of meat quality in poultry. Therefore, these traits also could be used as a meat quality indicator in this broiler line.

Lightness could be the best meat quality indicator among all the traits studied, since it presents the most easily measurement on the industrial slaughtering line.

\section{ACKNOWLEDGEMENTS}

The authors are grateful to Conselho Nacional de Desenvolvimento Científico e Tecnológico ( $\mathrm{CNPq}$ ) for the scholarship granted.

\section{REFERENCES}

ANADÓN, H.L.S. Biological, nutritional and processing factors affecting breast meat quality of broilers. 2002 . 171f. Tese (Doctor of Philosophy in Animal and Poultry Sciences) - Virginia Polytechnic Institute and State University. Available from: <http://scholar.lib.vt.edu/theses/available/etd02212002-113821/unrestricted/Dissertation.pdf >. Accessed: 10 ago. 2010.

ANTHONY, N.B. A review of genetic practices in poultry: efforts to improve meat quality. Journal of Muscle Foods, v.9, p.2533, 1998. Available from: <http://onlinelibrary.wiley.com/doi/ 10.1111/j.1745-4573.1998.tb00641.x/abstract>. Accessed: 10 ago. 2010. doi: 10.1111/j.1745-4573.1998.tb00641.x.

BROSSI, C. et al. Estresse térmico durante o pré-abate em frangos de corte. Ciência Rural, v.39, n.4, p.1296-1305, 2008. Available from: <http://www.scielo.br/pdf/cr/v39n4/ a145cr38.pdf >. Accessed: 10 ago. 2010.

DEBUT, M. et al. Variation of chicken technological meat quality in relation to genotype and preslaughter stress conditions. Poultry Science, v.82, p.1829-1838, 2003. Available from: <http://ps.fass.org/cgi/reprint/82/12/1829.pdf>. Accessed: 10 ago. 2010.

DIRINCK, P. et al. Studies on vitamin E and meat quality. 1. Effect of feeding high vitamin E levels on time-related pork quality. Journal of Agricultural Food and Chemistry, v.44, p.65-68, 1996. Available from: <http://pubs.acs.org/doi/ abs/10.1021/jf940607x>. Accessed: 10 ago. 2010. doi: $10.1021 /$ jf $940607 x$.

FERNANDEZ, X. et al. Effects of the rate of muscle post mortem $\mathrm{pH}$ fall on the technological quality of turkey meat. Poultry Science, v.43, p.245-252, 2002. Available from: <http://www.ncbi.nlm.nih.gov/pubmed/12047089>. Accessed: 10 ago. 2010. doi: 10.1080/00071660120121463.

HENRIQUES, A. et al. Estudos correlacionais e estudos causal-comparativos. Lisboa: Instituto de Educação, Faculdade de Lisboa, 2004. Available from: <http://www.educ.fc.ul. pt/ docentes/ichagas/mi1/t 1 textoestcorrelacionais.pdf $>$. Accessed: 18 abr. 2010.

LE BIHAN-DUVAL, E. Genetic variability within and between breeds of poultry technological meat quality. World's Poultry Science Association Journal, v.60, p.331-340, 2004. Available from: <http://journals.cambridge.org/action/ d i s p 1 a y F u 11 t e x t ? t y p e $=6 \&$ f i d $=623$ $304 \&$ ji d $=$ W P S \& v o 1 u m e Id $=60$ \& is s u e I d $=$ 03\&aid=623300\&fulltextType $=$ RV \&fileId $=$ S0043933904000273 $>$. Accessed: 14 mar. 2011. doi: 10.1079/WPS200321.

LE BIHAN-DUVAL, E. et al. Broiler meat quality: effect of selection for increased carcass quality and estimates of genetic parameters. Poultry Science, v.78, p.822-826, 1999. Available from: 〈http://ps.fass.org/cgi/reprint/78/6/822.pdf〉. Accessed: 10 ago. 2010.

LE BIHAN-DUVAL, E. et al. Estimation of the genetic parameters of meat characteristics and their genetic correlations with grow and body composition in a experimental broiler line. Poultry Science, v.80, n.7, p.839-843, 2001. Available from: <http://ps.fass.org/cgi/reprint/80/7/839.pdf>. Accessed: 10 ago. 2010 .

LE BIHAN-DUVAL, E. et al. Genetic parameters of meat technological quality traits in a grand-parental commercial line of turkey. Genetics, Selection, Evolution, v.35, p.623635, 2003. Available from: <http://www.ncbi.nlm.nih.gov/pmc/ articles/PMC2 698002/pdf/1297-9686-35-7-623.pdf >. Accessed: 10 ago. 2010. doi: 10.1051/gse:2003043.

MOLETTE, C. et al. Effect of rate of $\mathrm{pH}$ fall on turkey breast meat quality. British Poultry Science, v.44, p.787-788, 2003. 
MOREIRA, J. et al. Efeito da densidade populacional sobre desempenho, rendimento de carcaça e qualidade da carne em frangos de corte de diferentes linhagens comerciais. Revista Brasileira de Zootecnia, v.33, n.6, p.1506-1519, 2004. Available from: <http://www.scielo.br/pdf/\%0D/rbz/v33n6/ a18v33n6.pdf>. Accessed: 10 ago. 2010.

OFFER, G.; KNIGHT, P. The structural basis of water-holding in meat: general principles and water uptake in meat processing. In: _____. Developments in meat science. New York: Elsevier, 1988. p.63-171.
OLIVO, R. et al. Fatores que influenciam na cor de filés de peito de frango. Revista Nacional da Carne, v.25, n.289, p.44-49, 2001.

SAMS, A.R. Meat quality during processing. Poultry Science, v.78, p.798-803, 1999. Available from: < http://ps.fass.org/ cgi/reprint/78/5/798.pdf>. Accessed: 10 ago. 2010 .

SAS INSTITUTE. Statistical analysis systems user's guide. Version 8. Cary, 1999. 1464p.

VIDAL, A.G.R. Fox Pro for Windows básico. São Paulo: 1994. 638p. 